\title{
FEATURE OF ISLAM WHICH IS DISTINGUISHED FROM OTHER RELIGIONS
}

\author{
Mohamed Omar Moftah and Ahmed Elsaddig Dawelnor Abdel Gadir \\ Universiti Science Islam Malaysia email: medon_m@yahoo.com, saddig7@ \\ hotmail.com
}

\begin{abstract}
Abstrak
Beberapa orang yang tidak memahami konsep dasar nasionalisme atau toleransi beragama mencoba untuk mengadu nasionalisme dengan mengatasnamakan agama tanpa terlebih dahulu memahami makna dan kemuliaan Islam, yang memiliki semangat patriotisme, mengajak manusia untuk bertoleransi dan memberi kemudahan. Pada kenyataannya, kedua nilai ini, toleransi dan kemudahan, dianggap sebagai salah satu fitur utama dari kebudayaan Islam. Salah satu manifestasi dari konsep ini adalah diterimanya dan difasilitasinya nilai-nilai, aturan-aturan, dan bentuk-bentuk budaya dari para pemeluknya di seluruh dunia. Sehingga jelaslah pentingnya kajian ini sebagai penjelas tentang kemudahan dan toleransi yang diberi oleh ajaran Islam yang telah terbukti berdasarkan pengalaman dan realita kehidupan. Berkat kedua nilai inilah Islam dapat menjawab semua tantangan dan rintangan peradaban manusia sejak agama ini lahir. Oleh karena itu, pendekatan induktif dan historis diadopsi untuk menunjukkan toleransi dan kemudahan agama Islam. Diantara temuan yang ada dalam tulisan ini mengungkapakan bahwa Islam telah menggariskan persamaan hak dan derajat manusia tanpa membeda-bedakan manusia berdasarkan agama, kepercayaan, warna kulit dan kewarganegaraan. Toleransi dan kemudahan dalam Islam juga telah membuktikan solidaritas sosial; agar yang kaya dapat memberi pada yang miskin, dan yang yatim piatu boleh mencari orang tua yang beragama Islam yang peduli terhadap mereka.
\end{abstract}

The few people who do not understand the meaning of nationalism and the easiness of religions try to attack nationalism by the name of religion without comprehending the sublime meanings of Islam, which have made holy nationalism and called for easiness and facilitation. Easiness and facilitation is considered as the first feature of the Islamic civilization, one aspect of its manifestations, and 
the first that encourages its acceptance by way of its carrying values, legislations, manners and cultural patterns. The importance of this paper is to show easiness and facilitation that Muslim civilization brought and applied in reality by which it won amazing bets in wars of challenge and interaction with the other world civilizations. Due to this, the inductive and historical approach has been adopted to show Islam's easiness and facilitation. Among the results of this paper is the revelation that Islam put the first universal statement in rights of citizenship without discriminating among followers of religions, doctrines, races, or colors. Also, easiness in Islam has established social solidarity: the rich give the poor; and the orphans seeks other Muslims as their father.

Kata kunci: toleransi, kemudahan, Islamic civilization

\section{Introduction}

Islamic Sharia is distinguished by its easiness and tolerance; it attains with all updated life events; and its response to Muslims' needs in all places and at all times. Therefore, most of its laws are changing due to Muslims' interests; and the saying: "the difference of Muslim scholars is a mercy", has become well known in our scholarly legacy. Muslim scholars have, at all times, shown the most wonderful thought life images; and their opinions and thinking efforts have varied. They have enriched our scholarly and thought life with their scholarly thinking (i.e. ijtihad) which still enlightens the guidance path for Muslims and urges them to apply their minds for the service of their religion and nation. Facilitation in presenting the laws of Islamic Sharia, the banner of which all moslem scholars and thinkers have raised up in all ages, and in the modern age in particular, is a compulsory and Islamically sought in itself. This is not due to a response to reality pressure or in harmony to the spirit of the age as some people could imagine. But The Islamic Sharia is founded on easiness not hardship; its teaching to people is based on facilitation not hardship; and the call for it depends on revealing what makes people come along, not what makes them go away.

\section{Easiness and Facilitation in Islam}

\section{Easiness Linguistically and Terminology}

Easiness in language: flexibility and simplicity; submission is against force. Facilitation: when something is facilitated, it is done in a smooth way and not made difficult; not made hard on oneself or others. In terminology, it is in agreement to its linguistic meaning; that is, it is work that does not exert soul or body; in other words, it is work that is easy, simple, and flexible. The 
meaning of the Prophet's hadith "This religion is easy" is as Ibnu al Atheer said: "Easiness is the opposite of difficulty as Ibnu al Atheer said: "Easiness is the opposite of difficulty something that means it is tolerant" (al Aql et al.).

Today, Islam encounters several big challenges and a fierce attack on its principles. Therefore, accusations and doubts are directed to it while it is devoid all of that. Among such accusations are that Islam is the religion of force, terror and opponent of international peace. Furthermore, it is accused of having values and approaches that contradict with what sound minds established. Every fair person knows that all such accusations are just falsifications, lies, and evidenceless talk. In addition, they are mere claims that are baseless. In contrast, the principles of Islam are based on what keeps peace and on what establishes justice and security worldwide and treats all people without discrimination. Islam balances needs and duties between people; Islam guarantees their human rights which maintain the bases of material and spiritual life.

\section{Easiness and Facilitation in Quran and Sunnah}

Allah (SWT) says:

"Allah intends for you ease and He does not want to make things difficult for you. (He wants that you) must complete the same number (of days), and that you must magnify Allah for having guided you so that you may be grateful to Him" (QS al Baqoroh: 185).

This ayah shows that Allah (SWT) wants, by His guidance, easiness, mercy, expulsion of uneasiness, etc. Despite the fact that the ayah is about permission in fasting, what is meant by it is generality as stated by more than one tafsir scholar. This is a reminder that Allah (SWT) shows His mercy for this nation and His want of easiness, not the opposite of it. When man looks at history in order to find a solution or guidance for what happened to Muslims in particular and to all world people in general at all times and places especially in public affairs, man does not find one like Muhammad (PBUH) an example and Imam. And if we look forward to secured and content future, one does find so but in Muhammad's teachings; whom Allah (SWT) describes saying:

"And We have sent you (O Muhammad) not but as a mercy for the Alamin (mankind, jinn and all that exists)" (QS al Anbiyaa': 107).

Allah (SWT) also says:

"And by the mercy of Allah, you dealt with them gently. And had you been severe and hard hearted, they would have broken away from about you; so pass over (their faults), and ask (Allah's) Forgiveness for them; and consult them in the affairs. 
Then when you have taken a decision, put your trust in Allah, certainly, Allah loves those who put their trust (in Him)" (QS Ali 'Imran: 159).

These are clear ayat that show us the basic description of Muhammad (PBUH) in his character and divine message and in all his conditions among people. Such descriptions were not just words but were a reality; they are still ringing in the world from east to west from the day of his call until the end of life. Islam's easiness and facilitation is one of its traits that distinguishes it from other religions, for the wisdom for which Muhammad (PBUH) was sent is to break the chains that tired the previous nations before the coming of Islam.

Man's appreciation for the grace of Allah (SWT), Iman, and winning in the Day of Judgment cannot be achieved but through by only doing positive role in earth based on Allah's Path but should also applying His commands for themselves and for others. Allah (SWT) says:

"Those who follow the Messenger, the Prophet who can neither read nor write (i.e. Muhammad PBUH) whom they find written with them in the Taurat (Torah) and the Injeel (Gospel) he command them for Al Ma'ruf (i.e. Islamic Monotheism and all that Islam has ordained) and forbids them from Al Munkar (i.e. disbelief, polytheism of all kinds, and all that Islam has forbidden); He allows them as lawful At Tayyibat (i.e. all good and lawful as regard things, deeds, beliefs, persons, foods); and prohibits them as lawful $\mathrm{Al}$ Khaba'ith (i.e. all evil and unlawful as regards things, deeds, beliefs, persons and foods), He releases them from their heavy burdens (of Allah's Covenant with the children of Israel), and from the fetters (bindings) that were upon them. So those who believe in him (Muhammad صلى الله عليه وسـله), honour him, help him, and follow the light (the Quran) which has been send down with him, it is they who will be successful" (QS al A'raaf: lov).

Furthermore, Allah (SWT) says:

"But if you pardon (them) and overlook, and forgive (their faults), then verily Allah's Oft Forgiving, most Merciful" (QS at Taghaabun: 14).

The Islamic community, during the era of the Messenger (PBUH) and the era of Revelation has witnessed groups of Hypocrites who said to the Messenger as Allah (SWT) says about them in the Quran:

"We bear witness that you are indeed the Messenger of Allah" (QS al Munaafiquun: 1).

However, Allah (SWT) reveals their behavior and renders them liars when Allah (SWT) says:

"Allah knows that you are indeed His Messenger, and Allah bears witness that the hypocrites are liars indeed" (QS al Munaafiquun: 1).

In different hadith, Bukhari narrated that some companions of the 
Messenger (PBUH) asked him the permission to kill one of the Hypocrites, the Messenger (PBUH) said: "Those are the ones that Allah (SWT) prevented me to kill” (Bukhary, 1378: 38).

This is because they have witnessed that there is no God but Allah and that Muhammad is His Messenger, their blood and money are secured; they have become citizens enjoying all the citizenship rights in the state of Islam (Khaled, 1412: 56).

\section{Legality of Easiness and Permission in Islam}

The thing that proves the easiness of Islam is what has been known of the legality of permission-something that is known for sure as a part of religion by necessity. Such matter of Sharia is an absolute proof of expulsion of uneasiness. And, therefore, if hardship in obligation is meant in Islam, there would have been no permission.

The agreement of all scholars that hardship is not part of obligation shows that it is not meant in Islam; this is established by way of induction of laws. It is also what reinforces pieces of evidence from the Islam's texts that this religion is easy. The warning against extremism is well known in legal texts where it becomes an absolute base.

In terms of Sharia, the fundamental aspect is permission until evidence of prohibition exists. Allah (SWT) says: "And We never punish until We have sent a Messenger (to give warning)" (QS al Israa': 15).

Hardship here brings easiness, for no obligation of the unbearable exists in Islamic Sharia, nor what brings extraordinary hardship; Allah (SWT) says: "We burden not any person but that which he can bear" (QS al An'aam: 152).

Furthermore, Islam brings benefits; when it commands, an advantage is to be gained; when it warns against something, a disadvantage is to be expelled. The Messenger (PBUH) said: "When a little of something makes a person drunk, the whole thing is prohibited" (Provided by Abu Dawud, Sunan). This is evidence that the reason of prohibition is the state of drunkenness which prevents mind to protect consciousness of things as practiced in society. (Al Tabari, 1987: 97).

Islam is therefore the religion of peace that the Islamic Sharia has sought to achieve. Allah (SWT) says:

"O you who believe! Enter perfectly in Islam (by obeying all the rules and regulations of the Islamic religion) and follow not the footsteps of Shaitan (Satan). Verily! He is to you a plain enemy" (QS al Baqarah: 208).

Allah (SWT) says to His Prophet (PBUH): "And We have sent you (O 
Muhammad PBUH) not but as a Mercy for the Alamin (mankind, jinn and all the exists)" (QS al Anbiyaa': 107).

The peace is but a fruit of mercy that the Islamic Sharia has come to establish (al Khateeb, 1369: 101).

Because Islam is the religion of peace, it refuses force; it also refuses the causes leading to it as shown through its general principles that the Islamic Sharia has brought. The Messenger (PBUH) said: "The religion [i.e. Islam] is easy; and when it argues, it always wins)" (Bukhary, 1378:16).

Ibnu Abbas said: "Some paganists, who killed many and practiced adultery, came to the Messenger (PBUH) and said: what you say and call for is good, but we want you to tell us whether there is a correction to what we have done."

Here, Allah (SWT) sent down these ayat of Quran:

"And those who invoke not other ilah (god) along with Allah, nor kill such person as Allah has forbidden, except for just cause, nor commit illegal sexual intercourse-and whoever does this shall receive the punishment. The torment will be doubled to him on the Day of Resurrection, and he will abide therein in disgrace. Except those who repent and believe (in Islamic Monotheism), and do righteous deeds, for those, Allah will change their sins into good deeds, and Allah Oft Forgiving, Most Merciful" (QS al Furqaan: 68-70).

This ayah was also sent down:

"Say: 'O ibadi (My slaves) who have transgressed against themselves (by committing evil deeds and sins)! Despair not of the Mercy of Allah: verily, Allah forgives all sins. Truly He is Oft Forgiving, Most Merciful" (QS al Zumar: 53).

In addition, in different hadith, Bukhari narrated that Ibnu Masud said that a man kissed a woman and came to the Prophet (PBUH) telling him what had happened. Here, Allah (SWT) sent down this ayah of Quran:

"And perform as Salat (Iqamat as Salat), at the two ends of the day and in some hours of the night [i.e. the five compulsory salat (prayers)]. Verily, the good deeds remove the evil deeds (i.e. small sins). This is a reminder (an advice) for the mindful (those who accept advice)" (QS Huud: 114). 'to whom is this ayah?' the man asked. "To whoever does in accordance with it from those of my Ummah," the Prophet (PBUH) said. (Bukhary, 1378: 140).

\section{Easiness as with the Messenger}

Practiced life of the Messenger (PBUH) was based on easiness and facilitation. He (PBUH) took easiness as an approach in his life. When he $(\mathrm{PBUH})$ was in a position to choose between two things, he would take the easier if no sin was there (Bukhary, 1378: 198).

Additionally, the Prophet (PBUH) used to direct his messengers to adopt easiness and facilitation. $\mathrm{He}$ (PBUH) said: to Mu'ath and Abi Musa when he 
(PBUH) sent them to Yemen: "Make it easy not difficult and say what makes people get along not what makes them go away" (Bukhary, 1378: 34).

Clearly, that this facilitation is what goes along with Sharia and justice, not based on whims. For, if it were based on whims, there would not have been obligation in the first place. For, obligation has a sort of hardship in it. The Messenger (PBUH) liked kindness; he used to call for it. Consider what 'Aisha said concerning this: that the Messenger (PBUH) said "Kindness beautifies everything that goes with it; and when it is gone from a thing, that thing becomes bad" (Muslim, 676: 2004). In other hadith, he (PBUH) said: "Allah is kind, likes kindness, gives for kindness what he does give for force" (Muslim, 676: 2004).

In different hadith, it is narrated that the Messenger (PBUH) was the nicest person in his call and the kindest man with people. Abi Hurairah narrated: "A drunken man was brought to the Prophet (PBUH), the Prophet (PBUH) said: beat him; Abu Hurairah said: some were beating him with hands; others with shoes; yet others with clothes. When the man was leaving, some said to him: shame on you. Here the Prophet (PBUH) said: do not say so; do not help Satan on him" (Bukhary, 1378: 197). Jaber Ibnu Abdullah said that the Messenger (PBUH) said: "Allah did not send me a person who tires people nor a hard man but a teacher who makes things easy" (Al Shatibi, 790: 122). Mu'awiyah Ibnu al Hakam al Salami said: "While I was praying with the Messenger (PBUH), a person sneezed. I said'May Allah have His mercy on you'. When people looked at me, I said: why do you look at me? They kept patting their hands on their thighs. When I realized their attempt to keep me silent, I kept silent. I have not seen a better teacher than him (PBUH); he (PBUH) never shouted at me, beat me, nor abused me. He (PBUH) said: nothing of people's talk is allowed in this prayer; it is only tasbeeh, takbeer, and reading Quran" (Muslim, 676: 38). Anas Ibnu Malek said that the Messenger (PBUH) said: "Make things easy on people, not otherwise; and say what makes people get along, not what makes them go away" (Bukhary, 1378: 167).

\section{Idea of Easiness Brought by Sharia}

The idea of easiness that the Sharia brought is that Allah (SWT) has made this religion (i.e. Islam) a religion of fitrah. For fitrah lies in souls which accept its affairs easily. Hating strictness and force is a quality of fitrah. Allah wanted this Sharia and its continuity. This entailed that its spread among the Ummah is easy. This cannot be done unless force is expelled from it (Achour, 1978: 6). Abi Hurairah said: when an Arab peed in Masjid, people grabbed him to beat him, but the Prophet (PBUH) told them: "Leave him and pour some water on his urine. You are sent to make things easy, not otherwise". The Messenger (PBUH) showed that what his companions did was a strictness that contradicts 
the tolerance and easiness of Islam (Al Qurtubi, 1954: 107).

The following hadiths are but some illustrations of the Prophet's way of dealing with the disobedient and wrong doers. The religion (i.e. Islam) is a witness that the disobedient is not considered a disbeliever. When it is punished based on Islamic principles, it is a correction for him and purification for society. And he whom Allah covers him and then he repents, he is given to Allah: whether to forgive him or otherwise. Ubadah Ibnu al Samet said: we were with the Messenger (PBUH) when he (PBUH) said: "Promise me that you will not worship anyone with Allah, that you will not steal, and that you will not commit adultery; those who fulfill their promise, Allah will reward them; and those who break some of their promises and Allah coverthem, they are left to Allah: whether to forgive them or otherwise" (Bukhary, 1378: 11). Lastly, not only bringing easiness, Islam sharia but also has urged on covering faults. AbiHurairah said that the Messenger (PBUH) said: "If a person covers another in this life, Allah will cover him in the Day of Judgement" (Damietta, 1406: 113).

To conclude, Islam calls in its Sharia to balance in worship and warns against extremism and exaggeration, not only in idea but also in action. It urges for dialogue especially when calling for Truth. Moreover, it is concluded indisputably, that Islam urges for tolerance and easiness. Therefore, any extremist claim cannot be said to represent Islam which rejects it for its contradiction with it.

Regarding those extremist claims such as the western media claim that, in Egypt, Iraq, Lebanon and other Arab states, there is a campaign against Christian minority. Such claim is false; and the Islamic media have to explain so showing that the conflict between minorities exist everywhere whether in the east or the west. In America, constant conflicts exist among the minorities which originally came from Cuba and Haiti. There is also conflict between the Americans of African origin as well as the Americans of Spanish origin. One can also see conflict among the Jews who were born in America and those who migrated from Iran. A conflict also exist among the Turks and the German in Germany; among Cuban and Philippines in Japan; and in Israel constant conflicts exist between Zionist Defense Bond which is supported by the Americans and the migrants from other countries (Al Khatib, 1369: 96).

As matter of fact, Christians in the Arab states, they live in conformity with Muslims as one nation; united by nationality-all are Arabs, no minority or majority divisions exist there. They have one language, same customs and tradition. The base among religions is that of ethics, doctrine and Sharia. 
Therefore, the claim that the Arabs persecuted the Christians is mere falsification. It is a western attempt to distort the image of Islam. Such media claims must be countered by conscious media that get resource from Quran and the teachings of the Messenger Muhammad (PBUH) that is fit for all times and places and for all nations, that does not differentiate between Arab or non-Arab except by piousness and that in which there is no compulsion in religion; there is complete respect for each religion.

In the light of the stance of Islam toward the Christians is very clear. For, the ayah of Quran is very clear:

"And argue not with the people of the Scripture (Jews and Christians), unless it be in (a way) that is better (with good words and in good manner, inviting them to Islamic Monotheism with His Verses), except with such of them as do wrong" (QS al 'Ankabuut: 46).

This is a common matter; Allah (SWT) says:

"And say (to them): "We believe in that which has been revealed to us and revealed to you; our Ilah (God) and your Ilah (God) is One (i.e. Allah); and to Him we have submitted (as Muslims)'” (QS al 'Ankabuut: 46).

Allah (SWT) makes the argument with non-Muslims a regulated matter; that is, it should be in the best manner possible; Allah (SWT) says: "And argue not with the people of the Scripture"; He does not say argue with them. Therefore, any argument without the best manner possible with the Jews and Christians is completely rejected. Allah (SWT) says: "Except with such of them as do wrong"; this is a special case the judgment of which in every dialogue is known: the one who did injustice has another consideration; any other application to this rule cannot be considered Islamic.

1. Islam is the first to put a universal statement in citizenship without any discrimination between followers of religions, doctrines or differences in color or race. Islam has preceded the world in declaring the first statement for human rights at the beginning of building the first Islamic state and the most fantastic model in national unity and humane brotherhood in Madinah. Islam presented so as the first earthly constitution: it is declared that all people of Madinah are brothers united by brotherhood and the national spirit.

2. The easiness approach in Islam has established the social solidarity: the rich give the poor; and the orphan finds in all Muslims fathers caring and providing help for him. The ayat of Quran and the hadith of the Prophet (PBUH) that talks about caring for the orphans and the poor are many. After all this, do we find some people say that Islam is a complicated 
religion, difficult to adhere to or apply it and that it is not fit for this time or that!

3. Easiness and tolerance in Islam is an essential clear feature of it; and it is this feature that made people embrace it.

\section{Conclusion}

Allah (SWT) has made this blessed Sharia easy and simple; and $\mathrm{He}$ (SWT) has made people love. If they neglected or ignored it, then they would make a mistake with which their deeds would not be pure. Do you not see what Allah (SWT) says:

"And know that among you there is the Messenger of Allah. If he were to obey you (i.e. follow your opinions and desires) in much of the matter, you would surely be in trouble. But Allah has endeared the Faith to you and has beautified it in your hearts, and has made disbelief, wickedness and disobedience (to Allah and His Messenger) hateful to you. Such are they who are rightly guided" (QS al Hujuraat: 7).

This ayah tells-as al Shatiby said-that Allah has made Iman interesting to us by making it easy and simple, has made it interesting for our hearts, and has promised to reward us (if we adhered to it) (Al Shatiby, 790: 136).

Easiness is a common characteristic of Islamic Sharia in its essential laws as well as in its emerging laws where excuses are offered without extraordinary hardship (Al Shatiby, 790: 121). This is so because Islam does not ask for difficult things. All Sharia matters indicate clearly that it a religion of easiness and tolerance, that is, no exaggeration is there. The Messenger (PBUH) said: "Be aware of exaggeration in religion; the ones before you have gotten the Wrath of Allah because of their exaggeration in religion". What has been proved to be from religion is easiness; it is what has nothing of exaggeration and hardship in it. The Messenger (PBUH) said: "This religion is easy; when it argues it wins. Make things easy; reveal what makes people come along; be optimistic."

\section{References}

Achour, Mohamed Tahar. 1978. The Purposes of Islamic Law (1st Edition). Tunisia: Tunisian Company.

Al Khatib, Abd al Karim. 1369. Islam in the Face of Atheists. Beirut: House Sunrise.

Al Qurtubi, Abu Abdallah Mamed Ibnu Ahmed Ansari. 1954. The Whole of the Koran. 
Al Shatiby, Abu Ishaq Ibrahim Ibnu Musa Ibnu Muhammad al Khatimy. 790 AH. Approvals in the Assets of the Law. Egypt: Major Commercial of the Printing Press.

Al Tabari, Muhammad Ibnu Jarir. 1987. Collector Statement in the Interpretation of the Koran. Beirut: Dar al Arab Thought.

Bukhary, Abu Abdullah Muhammad bin Ismail bin Ibrahim. 1378. Shahih al Bukhari. Beirut: Dar Ibni Katsir.

Damietta, Hafiz. 1406. . Mecca: Library and a Modern Renaissance Press.

Khalid, Muhammad. 1412. The Issue of Religious Extremism (from Al Arabi Magazine No. 104).

Muslim, Abu al Hasan. 676. Shahih Muslim. Beirut: Press Issa Halabi. 